\title{
The Unique Contributions of the Theological Librarian in Campus- Wide Programs of Faith Integration
}

Liz Leahy, Azusa Pacific Seminary and University Libraries, Azusa Pacific University

\begin{abstract}
Many Christian colleges and universities have academic programs that emphasize "faith and learning" or "faith integration." The religious or theological studies librarian can have a unique role in assisting faculty across the disciplines to develop a better awareness of theological writings and resources that might reflect spiritual themes within their discipline. This paper will suggest ways for theological librarians to collaborate with colleagues, highlighting integrative work at Azusa Pacific University-including one-on-one and classroom resource instruction, the development and use of faith integration and special collections, integrative coursework, and reading groups-and concluding with a few suggested resources.
\end{abstract}

\section{FAITH INTEGRATION: AN ATTEMPT AT A DEFINITION}

"According to the National Center for Education Statistics, there are more than 4,300 degree-granting institutions of higher education in the United States. These include nearly 2,600 private institutions, just over 1,000 of which define themselves as religiously affiliated. Of those, 140 Christian colleges and universities in the U.S. have found common cause in the mission of the Council for Christian Colleges and Universities (CCCU).” (Council of Christian Colleges and Universities, n.d., "Our Place")

A common theme at many of the CCCU campuses is the importance which is placed on faith integration or faith and learning. The campuses share three common goals: 1) to integrate biblical truth throughout academics, 2) a commitment to the moral and spiritual formation of students, and 3) a commitment to graduating students who will be a redemptive voice in the world (Council of Christian Colleges and Universities, n.d., "What Is Christian Higher Education?”). 


\begin{abstract}
"For Christian academics, faith integration begins with investigating research questions and methodologies that will contribute to the advance of the discipline and the gathering of meaningful content for teaching, scholarly projects, and performances. It is here that the curious Christian intellectual (whether prepared in the sciences, liberal arts, the fine or performing arts, or the professions) will discover places where the knowledge of their discipline and the themes from the Christian faith intersect and invite further development." (Azusa Pacific, n.d.) Paul Kaak, Executive Director, Office of Faith Integration, Azusa Pacific University
\end{abstract}

This requires significant work on the part of faculty-to consider the questions that faith brings to their academic disciplines-in an area of research often new to those outside the theological disciplines. This is where the theologically trained librarian can contribute to conversations and partner on faith integration.

\title{
PARTNERING WITH SCHOOLS AND DEPARTMENTS ACROSS YOUR COLLEGE/UNIVERSITY
}

Librarians have a unique vantage point to view their institutions across the various disciplines taught. Service on committees, research instruction, and campus-wide activities provide opportunities to get to know other faculty and to learn of their research interests. This awareness can be particularly helpful as the theological librarian can serve as a connector between theological resources (what I refer to as the "great cloud of witnesses" [cf. Hebrews 11 and 12, NRSV]) and the research or teaching interest. If your campus publishes a list of recent faculty scholarship and grants, this can be an excellent resource in which to make connections. Make an effort to read recent articles published by colleagues and gain an awareness of research interests in your community.

\section{UNIQUE TOOLS A THEOLOGICAL LIBRARIAN BRINGS}

Theological librarians bring their theological training and resource knowledge into dialogues with their colleagues. Recognize that faculty have expertise in their disciplines but may have limited academic background in biblical or theological studies. Your bibliographic and theological knowledge as well as an awareness of resources in your collections might be just the ticket to connect the dots between theology and a specific discipline. 


\section{THEMES}

One way to do this is to consider themes that might be present in syllabi or in department goals. Offer to come alongside colleagues to help determine themes that connect with scripture or theological study with ideas that are important within their discipline. For instance, in a nursing program, consider themes of healing, compassion, hope, anger, prayer. How are these themes depicted in the scriptures? In the history and literature of the church? In a business program, consider perhaps themes of riches and poverty, biblical justice, or organizational behavior. In social work programs, consider people made in the image of God, what the scriptures teach about families or marriage, justice, poverty. Each of these themes have rich resources, and the theological librarian can instruct on the use of commentaries and dictionaries, writings from the early church including sermons and letters, and ways in which contemporary denominations are considering specific issues by looking at theologians in their denominational traditions.

As departments become more comfortable in considering themes in their disciplines, promote the idea of themes across a degree program with buildable goals for each semester. As an example, APU's Masters of Athletic Training has a six-semester Master of Science degree in which students study in cohorts. Each class has integration themes such as mind-body-spirit, service and compassion, healing, truth and wisdom, etc., which have been developed by the program faculty. By the time the program concludes, relevant themes are studied and assignments given across the curriculum (Azusa Pacific University 2021). The theological librarian can collaborate with the discipline faculty to provide resources and ideas based upon these identified themes as well as provide in-class instruction for students.

\section{COLLECTIONS}

A second way to do this can be through collection development. Consider developing a special collection of faith integration materials across all disciplines taught at your campus, along with good overview resources. Placed together (instead of, or in addition to the disciplines), the collection can assist faculty whose discipline interests might span more than a single idea or theme. It is also helpful for disciplines where there has not been much published. For example, 
in librarianship, a few books are specific to faith and learning, but we might also consider resources on pedagogy or technology as well.

At APU, we were able to begin this collection with an external grant from an organization with an expressed interest in integrating faith and learning. The collection is housed in the theological library and adjacent to the reference collection, so that a theological librarian is available for questions and collection recommendations. Faculty members are often surprised at the number of resources written in areas of their interest, but they can also see where the gaps are and find encouragement for their own scholarship. While external foundations with this shared interest might be difficult to find, let your development office know of this interest; this might be something to which a university donor would like to contribute funds.

If your campus maintains special collections related to the institution's religious roots, this can be a wonderful resource for faculty and students seeking primary sources. Often faculty outside of the theological department will not be aware of these holdings, but they might have relevance for courses in history or literature as well. Offer a tour for faculty and have items pre-selected to highlight. Encourage them to consider assignments that students might be able to accomplish and potentially give assignment suggestions.

At APU, we have Holiness denominational collections including a large collection of Salvation Army and Friends churches materials. We also have a growing collection of Clapham saints materials (William Wilberforce and friends). Our social work, history, and political science faculty have been encouraged to view these resources and connect the biographical dots of people of faith. Students learn how their faith informed their work to change legislative policies related to slavery and abolition, usury, and working conditions among the poor. Our literature students can consider what it means to be a part of a community and how to encourage faith development as they reflect on materials from the Oxford Inklings collection (C.S. Lewis, J.R.R. Tolkien, and friends).

\section{INSTRUCTION}

Consider offering a series of workshops that will inform faculty of resource tools that might be helpful in their work. If your campus has an office responsible for faith and learning, seek out opportunities to teach short bibliographic sessions. At our new faculty workshop 
series on faith integration, an hour is set aside for hands-on review of biblical dictionaries, commentaries, theological tools and the Atla database. A second workshop, taught by my colleague Lindsey Sinnott, features more in-depth instruction on biblical tools. This is a great opportunity for faculty across your campus to get to know you and the work you do, as well as to set up future one-on-one appointments or classroom visits.

Plan one-on-one appointments with faculty colleagues for syllabi discussion-perhaps figuring out assignments that might aid a student's understanding/application of faith. If your campus faculty prepare a research paper for promotion or tenure related to their application of faith and learning, see if you can get a few ideas in advance from them, such as their denominational background (if your campus has a variety of denominations represented) and information related to the courses they regularly teach or research they are conducting. Then do some of the connecting work in advance and have resources pulled from your collections or articles available which might help in using time together well. Once faculty learn of you as a resource-and your collections-cross-disciplinary collaborations can begin.

Bibliographic guides to the literature, such as LibGuides, are useful teaching tools as well. My former colleague, Michelle Spomer, created a LibGuide for faith integration resources that connects relevant LC Subject Headings with the disciplines taught at our university. As new titles are added to the collections, they are readily located through this helpful guide.

\section{READING GROUPS}

Some of the departments in your institution may choose one or more readings each semester to encourage faith integration dialogue. You might encourage this by passing along books and articles that are relevant. The Economics faculty at APU were delighted to receive my note about a recent Christian History magazine issue entitled "When the Church Goes to Market” and now plan to purchase print copies for all of their majors. Our Nursing and Biology faculty received information about another Christian History issue, on "Plagues and Epidemics" and several plan to include readings in their classes this fall (thank you to Atla member and Christian History editor, Jennifer Woodruff Tait, for this excellent publication!). Often, books with faith 
integration themes appear in vendor catalogs that cater to religious and theological collections and may not find their way to faculty in other disciplines, so sending along the information with a note is a great way to connect!

\section{A FEW RESOURCES}

Christian Scholars Review: https://christianscholars.com Publishes peer-reviewed scholarship across the disciplines that advances the integration of faith and learning. Journal is published quarterly and weekly blog posts.

For information on Christian professional societies: https://christianscholars.com/resources/\#societies

Christian History magazine: https://christianhistoryinstitute.org/ magazine

Written by historians and scholars for a lay readership, it is a wonderful introduction to people and ideas across the span of Christian history.

The Trinity Forum: https://tfforg

The Trinity Forum "endeavors to cultivate, curate, and disseminate the best of Christian thought, to equip leaders to think, work, and lead wisely and well.” The Forum regularly hosts speakers on Christian thought and culture (https://www.ttf.org/video/). Membership includes a wide range of curated readings and introductions to classic literature.

Emerging Scholars Blog: https//blog.emergingscholars.org The Emerging Scholars Network (ESN) is a national network within Intervarsity's Graduate and Faculty Ministries that "supports those on the academic pathway as they work out how their academic vocation serves God and others." 


\section{REFERENCES}

Azusa Pacific University. 2021. "MS in Athletic Training: About the Program.” Accessed August 30, 2021. https://www.apu.edu/bas/ programs/athletic-training-masters/about/.

Azusa Pacific University. n.d. "What is Faith Integration?” Accessed July 12, 2021. https://www.apu.edu/faithintegration/about/.

Council of Christian Colleges and Universities. n.d. "Our Place in Higher Education.” Accessed July 12, 2021. https://www.cccu.org/ about/.

Council of Christian Colleges and Universities. n.d. "What Is Christian Higher Education?” Accessed July 12, 2021. https://www.cccu. org/about/. 